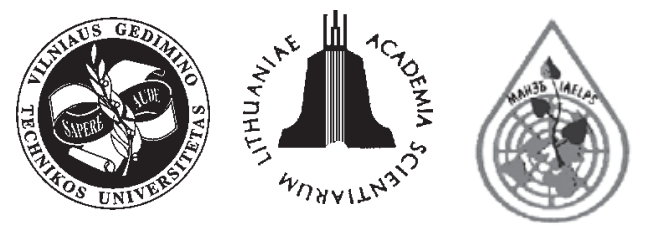

\title{
INFLUENCE OF LAND FIRES ON INCREASE OF HEAVY METAL CONCENTRATIONS IN RIVER WATERS OF LITHUANIA
}

\author{
Gytautas Ignatavičius ${ }^{1}$, Gaudenta Sakalauskienė ${ }^{2}$, Vytautas Oškinis ${ }^{3}$ \\ ${ }^{1}$ Ecology and Environmental Research Center, Vilnius University, \\ M. K. Čiurlionio g. 21/27, -LT-03101 Vilnius, Lithuania. E-mail: gytisi@takas.lt \\ ${ }^{2}$ Environmental Protection Agency, A. Juozapavičiaus g. 9, LT-09311 Vilnius, \\ Lithuania.E-mail: g.sakalauskiene@aaa.am.lt \\ ${ }^{3}$ Dept of Environmental Protection, Vilnius Gediminas Technical University, \\ Saulètekio al.11,LT-10223Vilnius, Lithuania.E-mail: aak@ap.vtu.lt
}

Submitted 7 Sept 2005; accepted 10 Jan 2006

\begin{abstract}
Comparison of long-term environmental monitoring data show that in August and September 2002 heavy metal $(\mathrm{Cu}, \mathrm{Pb}$ and $\mathrm{Zn})$ concentrations increased in Lithuanian rivers. Resent investigation has indicated that increase of heavy metals $(\mathrm{Cu}, \mathrm{Pb}$ and $\mathrm{Zn})$ by $60-81 \%$ in all the rivers that are subject to the State River Monitoring and could be correlative with land fires. Fires of forests and peat bogs have outspread all over Lithuania in the summer and the first half of autumn of 2002. This paper attempts to prove an assumption that these fires could have caused a significant increase of heavy metal concentrations in the water of Lithuanian rivers in August 2002. It also means that land fires should be evaluated as an environmental risk factor with a serious impact on the state of aquatic environment and must be taken into account in calculations of environmental damage.
\end{abstract}

Keywords: environmental risk, heavy metals, land fires, river water pollution.

\section{Introduction}

Increasingly, negative anthropogenic loading on the natural environment affects the surrounding organic world [1]. Many environmental contaminants, that enter aquatic systems eventually deposit in the bottom sediments, where they can adversely affect benthic populations and cause changes in the structure and composition of resident communities [2].

A rapid growth of urban territories has led to an extensive residential and industrial expansion [3-5]. Anthropogenic activities associated with this expansion resulted in the movement of trace metals into rivers and streams [6].

More recently unusual changes in the geochemical composition of the environment have been observed chemical elements, not common in the natural environment and hazardous to biological diversity, have increasingly been found in the soil and river sediments [7]. Even secondary pollution of surface water and groundwater may occur [8]. Many dangerous chemical elements, if released into the components of the environment, accumulate in the soil and sediments beneath water bodies [9]. Such pollutants may reach the soil with dust, precipitation, or otherwise and may accumulate there in various chemical forms

[10], so that soil acts as both a depository and a transit medium [11].

Under certain conditions water may dissolve and leach these very hazardous substances to surface or groundwater bodies [12]. Furthermore, hydro-geological changes may trigger migration of chemical elements accumulated in the silt and bottom sediments of water bodies back into water [13, 14]. Hence, silt can become a source of secondary heavy metal pollution [15].

These processes may make water bodies unsuitable for human consumption and toxic to organisms living in water bodies. Heavy metals are more dangerous to living organisms than nitrates, carbon and sulphur dioxides or oil products, and the duration of their impact is unsurpassable $[16,17]$. Water plants and plankton on which fish feed can absorb hazardous elements accumulated in the bottom sediments and in surface water [18]. This may result in the migration of such pollutants through the food chain and their accumulation in living organisms, including humans, causing multiple impacts [19]. Therefore, the concentrations of heavy metals in the soil, water and sediments below water bodies are important 
geochemical environmental quality indicators that define the ecological status of a region [20,21].

Negative anthropogenic processes take place on a global scale [22] and, hence, also occur in Lithuania [23]. Certain geochemical trace elements, including heavy metals have increased a hundredfold in the soil and in the silt in water bodies, while in certain places pollution has reached or even exceeded the limits of environmental tolerance [24]. Such zones are potential sources of secondary environmental pollution.

\section{Problem}

The European Commmunity Council Directive 76/464/ EC of 4 May 1976 on pollution by certain dangerous substances discharged into the aquatic environment [25] is partly incorporated in the Lithuanian legislation. Maximum allowed concentrations in water bodies for $\mathrm{Zn}$ (Chemical Abstracts Service (CAS) - CAS 7440-66-6), Cu (CAS 744050-8) and $\mathrm{Pb}(\mathrm{CAS} 7439-92-1)$ ) are $100 \mu \mathrm{gl}^{-1}, 10 \mu \mathrm{gl}^{-1}$, and $5 \mu \mathrm{gl}^{-1}$, respectively. A maximum allowed concentration of a pollutant or group of pollutants in water is a concentration beyond which there are significant impacts on human health and the environment.

Compared with the previous years, in 2002 concentrations of heavy metals ( $\mathrm{Fe}, \mathrm{Cu}, \mathrm{Zn}, \mathrm{Cd}, \mathrm{Cr}, \mathrm{Ni}, \mathrm{Mn}, \mathrm{Pb}$, $\mathrm{Hg}$ ) surged in all the Lithuanian rivers monitored by the State. Concentrations of $\mathrm{Zn}, \mathrm{Cu}$ and $\mathrm{Pb}$ even exceeded maximum values allowed by law.

Such a sudden increase of heavy metal concentrations in Lithuanian rivers necessitates research into the reasons for this phenomenon which compromises opportunities to use a water body for fishing or recreation and even poses a risk to the environment and human health. Therefore, what has caused this seemingly spontaneous increase of concentrations of heavy metals in river waters if not industrial pollution sources? Is it possible to prevent this?

\section{Results}

The State Monitoring Program of Surface Water Bodies of the Republic of Lithuania analyses river waters for heavy metals $(\mathrm{Cu}, \mathrm{Zn}$ and $\mathrm{Pb})$ four times a year at 51 sites. Soils in Lithuania are grouped into twelve soil types - in the following plains: I - Littoral, III - Middle Venta, IV Lower Nemunas, V - Nevėžis, VI - Mūša - Nemunèlis, VII - Sūduva, XI - Southeastern; in the following highlands: II - Žemaičiai, VIII - West Aukštaičiai plateau, IX South Lithuanian, X - East Lithuanian, XII - Ašmena (Medininkai).

The statistical results of monitoring heavy metals ( $\mathrm{Cu}, \mathrm{Pb}$ and $\mathrm{Zn}$ ) for August in 1993-2002 are presented in Table 1 and Fig 1. Clearly, much higher concentrations of heavy metals $(\mathrm{Cu}, \mathrm{Zn}$ and $\mathrm{Pb})$ were measured in the surface water of Lithuanian rivers in August 2002.

In August and September 2002, concentrations of heavy metals $(\mathrm{Cu}, \mathrm{Pb}$, and $\mathrm{Zn})$ increased by $21-74 \%$ compared with those averaged over the previous 8 years in all the Lithuanian rivers that are subject to the State River Monitoring. Over the period 1993-2001 concentrations of $\mathrm{Zn}$ fluctuated between 2,9 and 26,0 $\mu \mathrm{gl}^{-1}$, while in August and September 2002 they ranged from 4,2 to $174,0 \mu \mathrm{gl}^{-1}$. A maximum allowed concentration (MAC) for $\mathrm{Zn}$ in surface water $\left(100 \mu \mathrm{gl}^{-1}\right)$ was exceeded in August 2002 in the rivers of the Southeastern plain, the Nemunas river $\left(174,0 \mu \mathrm{gl}^{-1}\right)$ and the Merkys river $\left(121,0 \mu \mathrm{gl}^{-1}\right)$ (Fig 2).

Over the period 1993-2001 concentrations of $\mathrm{Cu}$ in rivers ranged from 0,6 to $11,7 \mu \mathrm{gl}^{-1}$, while in August and September 2002 the range was from 0,6 to $26,1 \mu \mathrm{gl}^{-1}$. In $2002 \mathrm{MAC}$ for $\mathrm{Cu}\left(10 \mu \mathrm{gl}^{-1}\right)$ was exceeded in the following rivers:

in the Southeastern plain: the Neris river $\left(25,3 \mu \mathrm{gl}^{-1}\right)$, the Šalčia river $\left(13,2 \mu \mathrm{gl}^{-1}\right)$, the Merkys river $\left(26,1 \mu \mathrm{gl}^{-1}\right)$;

in the Lower Nemunas plain: the Nemunas river $\left(19,6-21,2 \mu \mathrm{gl}^{-1}\right)$;

in the Nevėžis plain: the Nevėžis river $\left(11,4 \mu \mathrm{gl}^{-1}\right.$ and $\left.15,5 \mu \mathrm{gl}^{-1}\right)$;

in the Mūša - Nemunèlis plain: the Sidabra river $\left(13,7 \mu \mathrm{gl}^{-1}\right)$;

in the Western Aukštaičiai plateau: the Šventoji river $\left(21,0 \mu \mathrm{gl}^{-1}\right)$ (Fig 3).

In the previous years higher concentrations of $\mathrm{Pb}$ were detected only in the most polluted Lithuanian rivers (the Nemunas, the Neris, the Sidabra, the Obele and the Kulpe), but maximum allowed concentrations were not exceeded.

In 1993-2001 concentrations of $\mathrm{Pb}$ in rivers ranged from 0 to 4,3 $\mu \mathrm{gl}^{-1}$, while in August and September 2002 they were between 0 and 26,7 $\mu \mathrm{gl}^{-1}$. Maximum allowed concentrations were exceeded in the rivers of the following plains: Southeastern, Lower Nemunas, Nevėžis, Mūša-Nemunèlis, South Lithuanian and West Aukštaičiai plateau. In fact, a maximum allowed concentration for $\mathrm{Pb}$ $\left(5 \mathrm{Mgl}^{-1}\right)$ was exceeded at 11 sampling sites in August September 2002: in the Nemunas river $\left(26,2 \mu \mathrm{gl}^{-1}\right)$, the Neris river $\left(11,0 \mu \mathrm{gl}^{-1}\right)$, the Šušve river $\left(6,2 \mu \mathrm{gl}^{-1}\right)$, the Šventoji river $\left(12 \mu \mathrm{gl}^{-1}\right)$, the Sidabra river $\left(26,7 \mu \mathrm{gl}^{-1}\right)$, the Obele river $\left(5,9 \mu \mathrm{gl}^{-1}\right)$ and the Merkys river $\left(14,7 \mu \mathrm{gl}^{-1}\right)$ (Fig 4).

\section{Discussion}

The two pathways by which trace elements appear in the natural environment and in water bodies, are from the atmosphere and from surface water pollution or ground water sewage (effluent). Since Lithuanian environmental control agencies have detected no emissions of industrial pollutants over the period under investigation, and since there are no potential pollution sources of this type near smaller rivers (like the Žeimena or the Merkys), possibility of industrial emissions is minimal. However, burning is also a potential source of heavy metals that can be released into the atmosphere through volatilization trapped in smoke particles or distributed as fly ash after combustion [26, 27]. Agricultural emissions are unlikely because in July and August no use is made of fertilizers or other 
agricultural chemicals in Lithuania. Also, precipitation was very low in the summer of 2002, so the Lithuanian rivers were "fed" by groundwater during August.

Due to the drought 497 forest and peat bog fires broke out in Lithuania in July and August (Fig 5). Land fires inevitably result in large quantities of ashes which acidify the soil. The acidic-alkaline indicator $(\mathrm{pH})$ is a very important factor in determining the background levels of trace elements. In August and September the days are quite warm in the territory of Lithuania - about $25-30{ }^{\circ} \mathrm{C}$, but at night the temperature drops up to $+5--2{ }^{\circ} \mathrm{C}$. Therefore, dews are characteristic of this season. Ashes sink down and interact with dews resulting in an acidic solution [28, 29]. Most heavy metals are inert and immobilized in the soil and river sediments, but under acidic conditions they may change into an ionic form and migrate into water.

Heavy metals could move through aquatic environments via few mediums [6]. Predominantly trace metals are absorbed onto particulate matter, although they can form free metal ions and soluble complexes that are available for uptake by water habitants [30]. Metals associated with particulate matter are also available for biological uptake [31] and are deposited in river sediments [32]. Once deposited, binding by sulfides and/or ion hydroxides immo- bilizes heavy metals until a change in redox or $\mathrm{pH}$ occurs $[32,33]$. Thus, surfical sediments, particularly the fine fraction accumulate heavy metals and induce a long-term accumulation of contaminants [32].

Hence, following intensive land fires, soils may become more and more acidic, and at $\mathrm{pH}$ values $<6$ heavy metal cations can migrate from the soil to groundwater. Likewise, as river bottom sediments become more acidic, the cations of heavy metals may migrate into river waters [34].

Taking into account the above factors, it is reasonable to assume that migration of heavy metals (i e secondary pollution), associated with reduction in natural geochemical barriers between the soil and groundwater as well as between river bottom sediments and surface waters, may have facilitated increase in concentrations of heavy metals in August 2002 in the surface water of Lithuanian rivers.

Accounting all the above mentioned factors, we should note that fires of large forests and peat bogs could initiate increase of heavy metal amounts in aquatic environment, and, therefore, they should be evaluated as an environmental risk factor with a serious impact on the state of aquatic environment and must be taken into account in calculations of environmental damage.

Table 1. Descriptive sampling statistics for $\mathrm{Cu}, \mathrm{Pb}$ and $\mathrm{Zn}$ concentrations at Lithuanian river stations in 1991-2000 and August 2002

\begin{tabular}{|c|c|c|c|c|c|c|c|}
\hline \multirow{2}{*}{ Period } & \multirow{2}{*}{$\begin{array}{l}\text { Number of } \\
\text { samples }\end{array}$} & \multicolumn{6}{|c|}{ Percentage of river water samples without excessive concentrations $(\mu \mathrm{g} / \mathrm{l})$} \\
\hline & & $10 \%$ & $25 \%$ & $50 \%$ & $75 \%$ & $90 \%$ & $99 \%$ \\
\hline \multicolumn{8}{|l|}{$\mathbf{C u}$} \\
\hline $1991-2000$ & 2588 & 0,005 & 0,01 & 1,3 & 2,9 & 5,13 & 14,8 \\
\hline 2002 & 68 & 1,1 & 1,95 & 3,3 & 6,1 & 14,0 & 25,7 \\
\hline \multicolumn{8}{|l|}{$\mathbf{P b}$} \\
\hline $1991-2000$ & 2056 & 0,0 & 0,002 & 0,6 & 1,1 & 1,8 & 6,3 \\
\hline 2002 & 48 & 1,2 & 1,9 & 3,1 & 5,6 & 9,8 & 22,7 \\
\hline \multicolumn{8}{|l|}{ Zn } \\
\hline 1991-2000 & 1815 & 0,03 & 0,007 & 6,4 & 11,0 & 16,2 & 25,6 \\
\hline 2002 & 48 & 10,2 & 27,3 & 40,6 & 63,6 & 80,4 & 146,4 \\
\hline
\end{tabular}

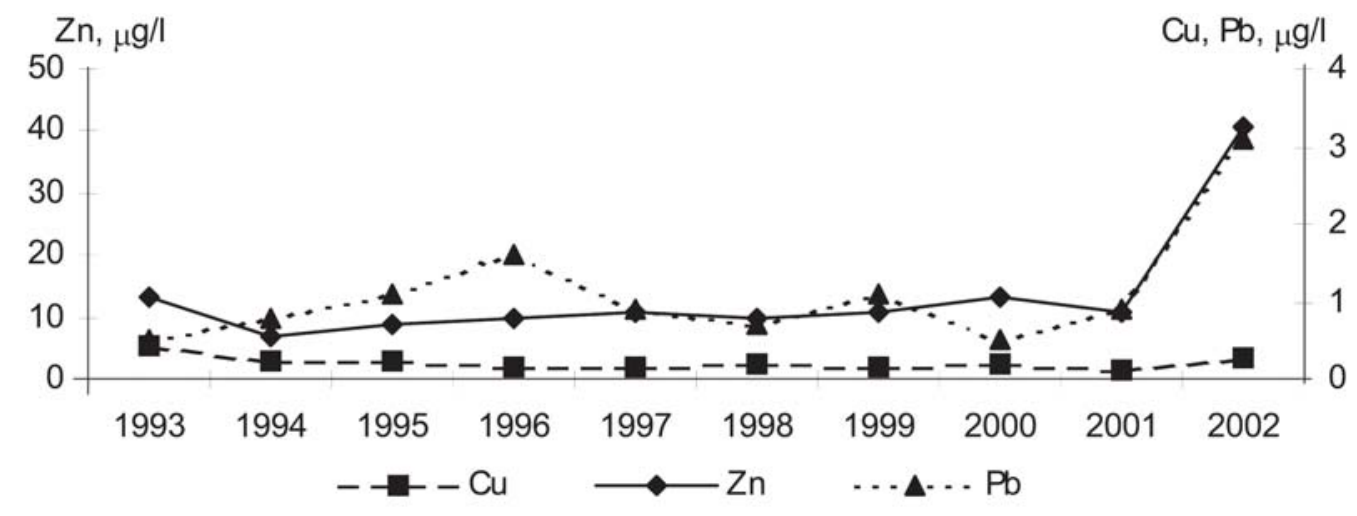

Fig 1. Mean concentrations of $\mathrm{Zn}, \mathrm{Cu}$ and $\mathrm{Pb}$ in Lithuania, 1993-2002 


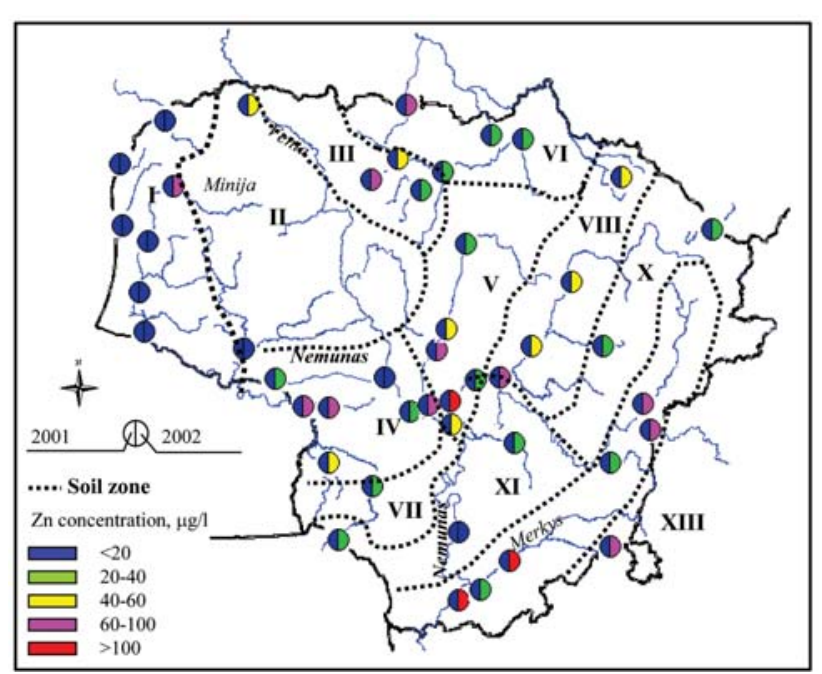

Fig 2. Zn concentrations at some monitoring stations in Lithuania, 2001 and 2002

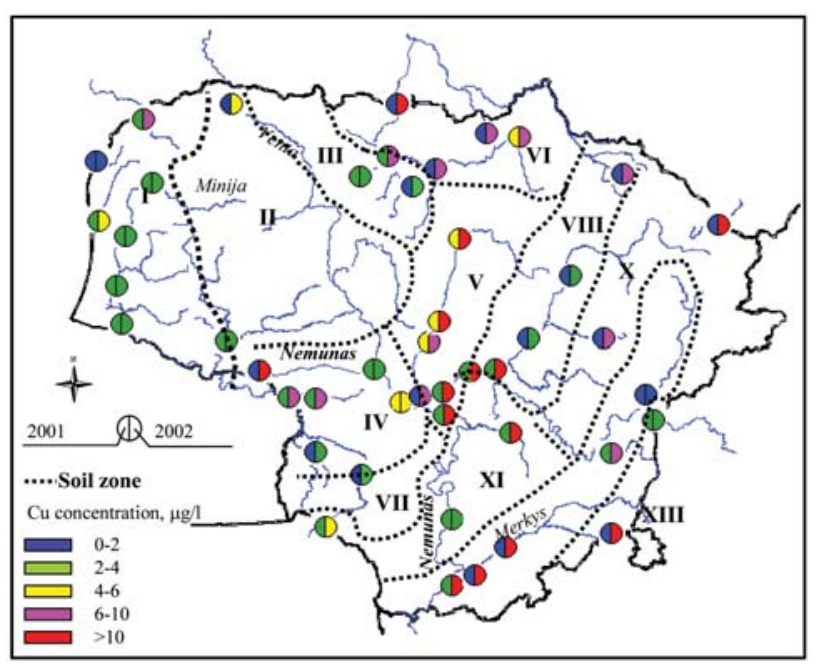

Fig 3. $\mathrm{Cu}$ concentrations at some monitoring stations in Lithuania, 2001 and 2002

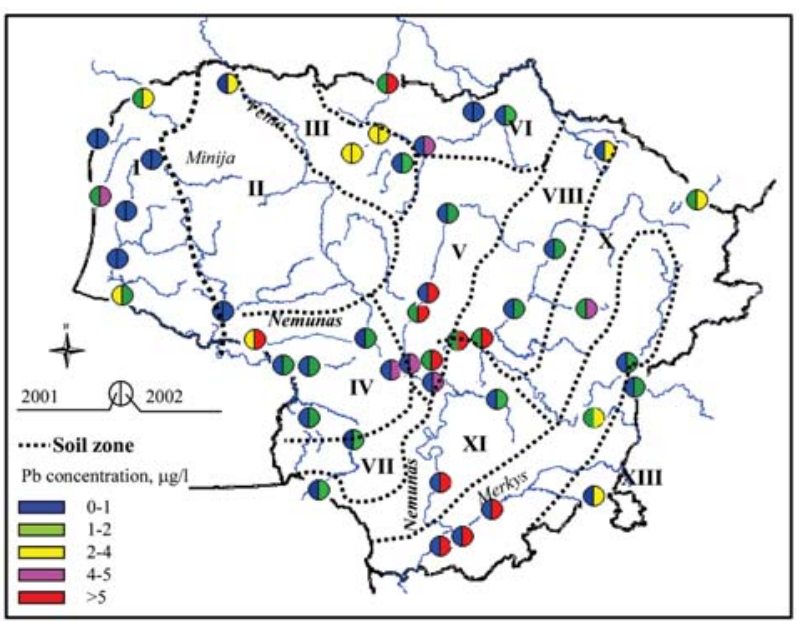

Fig 4. $\mathrm{Pb}$ concentrations at some monitoring stations in Lithuania, 2001 and 2002

\section{Conclusions}

1. In August and September 2002 concentrations of heavy metals $(\mathrm{Cu}, \mathrm{Pb}$ and $\mathrm{Zn})$ increased by $21-74 \%$ compared with those averaged over the previous 8 years (1993-2001) in all the Lithuanian rivers that are subject to the State River Monitoring.

2. The acidic-alkaline indicator $(\mathrm{pH})$ is a very important factor in determining the background level of trace elements. Due to the drought 497 fires of forests and peat bogs broke out in Lithuania in July and August 2002. Land fires inevitably result in large quantities of ashes which acidify the soil.

3. Migration of heavy metals associated with a reduction in natural geochemical barriers may have facilitated increase in concentrations of heavy metals in August 2002 in the surface water of the investigated Lithuanian rivers.

4. Fires of large forests and peat bogs could initiate increase of heavy metal amounts in aquatic environment, and, therefore, they should be evaluated as an environmental risk factor with a serious impact on the state of aquatic environment.

\section{References}

1. Gleditsch, N. P. Environmental Degradation. Migration and the Potential for Violent Conflict. In: Conflict and the Environment. Dordrecht: Kluwer, 1997, p 255-277.

2. Nipper, M.; Roper, D.; Williams, E.; Martin, M.; Van Dam, L.; Mills, G. Sediment toxicity and benthic communities in mildly contaminated mudflats. Environmental Toxicology Chemistry, 17, 1998, p 502-510.

3. Commission of the European Communities. Chemical controls in the European Community. Directorate-General XI Environmental, Nuclear Safety and Civil Protection. Cambridge: Royal Society of Chemistry, 1992.

4. Rogers, J. J. W.; Feis, G. P. People and the Earth. Basic Issues in the Sustainability of Resources and Environment. Cambridge: Cambridge University Press, 1998.

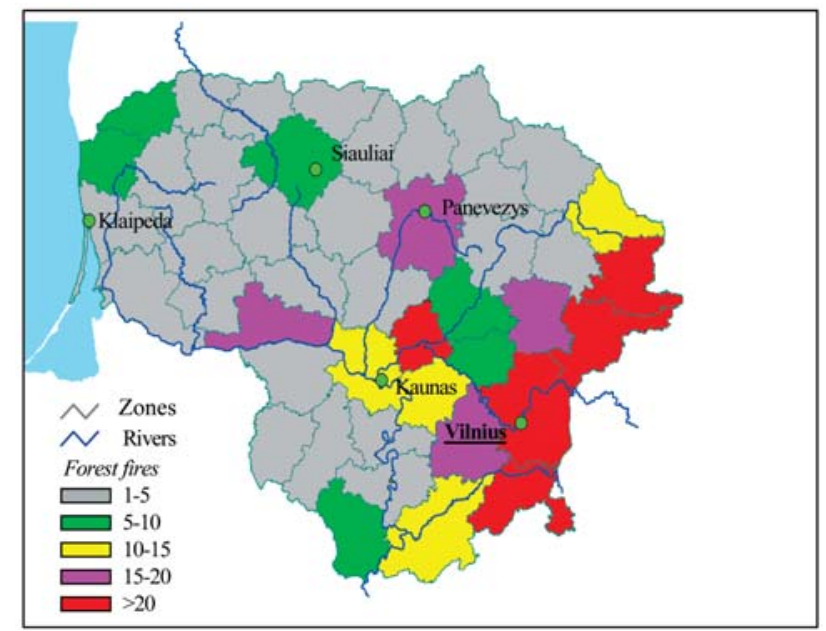

Fig 5. Distribution of forest and meadow fires in Lithuania in August 2002 
5. Hill, K. M. Understanding Environmental Pollution. Cambridge: Cambridge University Press, 1997.

6. Spooner, D.; Maher, W.; Otway, N. Trace metal concentrations in sediments and oysters of BOTANY Bay, NSW, Australia. Archyves of Environmental. Contamination, 45, 2003, p 92-101.

7. Wright, D. A.; Welbourn, P. 2002. Environmental toxicology. Cambridge Environmental Chemistry Series, 11, 2002.

8. Rasmussen, P. Trace metals in environment: A geochemical perspective. In: GSC Bulletin. Ottawa: Geological survey of Canada, 429, 1996.

9. Schuurmann, G.; Markert, B. A. Ecotoxicology. New York: Wiley, 1998.

10. Troeh, F. R.; Hobbs, J. A.; Donahue, R. L. Soil and Water Conservation. Englewood Cliffs: Prentice Hall, 1999.

11. Kabata-Pendias, A.; Pendias, H. Trace Elements in Soils and Plants. Boca Raton: CRC Press, 1994.

12. Campbell, P. G. C. Interactions between trace metals and aquatic organisms: A Critique of the Free-Ion Activity Model. In: Metal Speciation and Bioavailability in Aquatic Systems (Tessier, A.; Turner, D., Ed.). Chichester: J. Wiley \&Sons, 102, 1995.

13. Bedient, B. and others. Groundwater contamination, transport and remediation. Englewood Cliffs: Prentice Hall, 1993.

14. Bear, J. Dynamic of fluids in porous media. New York: Elsevier, 1996.

15. Crossland, N. O.; La Point, T. W. The design of mesocosm experiments. Environmental Toxicology and Chemistry, 11, 1992, p 1-4.

16. Effects of Chromium in the Canadian Environment. Ottawa, National Research Council of Canada, 1986.

17. Coale, K. H.; Flegal, R. H. Copper, zinc, cadmium and lead in surface waters of Lakes Erie and Ontario. Science of Total Environment, 87/88, 1989, p 297-304.

18. Suiter, G. V. Introduction to ecological risk assessment for aquatic toxic effects. In: Fundamentals of Aquatic Toxicology (Rand, G. M.; Ed.), 1995, p 803-816.

19. Callow, M. E.; Finlay, J A. The potential of alkyl amines as antifouling biocides. I. Toxicity and structure: activity relationships. Biofouling, 9, 1996, p 257-268.

20. Thorton, I. Metals in Global Environment: Facts and Misconceptions. In: International Council on Metals in Environment. Ottawa, 1995.
21. World Health Organisation (WHO). Inorganic Lead, Environmental Health Criteria, 165, 1995.

22. Connell, D. W.; Lam, P.; Richardson, B.; Wu, R. Introduction to Ecotoxicology. Malden: Blackwell Science, 1999.

23. Svecevičius, G. Acute toxicity of zinc to common freshwater fishes of Lithuania. Acta zoologica. Lithuanica. Hydrobiologia, 2, 1999, p 114-118.

24. Davis, R. D.; Backett, P. H. T.; Wollan, E. Critical levels of twenty potential toxic elements in young spring barley. Plant Soil, 49, 1988, p 382-395.

25. Council Directive 76/464/EC of 4 May 1976 on pollution caused by certain dangerous substances discharged into the aquatic environment of the Community. Official Journal of the European Communities, L 129/23.

26. Kagey, B.; Wixson, B. Health implications of coal development. In: Aplied environmental geochemistry (Thorton, I.; Ed.), New York: Academic Press, 1983, p 463-480.

27. Lipinskas, D.; Mačiulaitis, R. Further opportunities for development of the method for fire origin prognosis. Journal of Civil Engineering and Management, Vol 11, No 4, 2005, p 299-307.

28. Ernst, W. G. Earth Systems Processes and Issues. Cambridge: Cambridge University Press, 2000.

29. Duris, M. Geological and Ecological Survey of Prague agglomeration. Heavy metals in the environment: an integrated approach. In: The 1st International Conference "Metals in Environment", Vilnius, 15-17 October 1997. Vilnius: Karminas, 1999.

30. Salomons, W.; Foster, U. Metals in Hydrocycle. New York: Springer-Verlag, 1984.

31. Lee, B. G.; Griscom, S.; Lee, J. S.; Choi, H.; Koch, C. H.; Luoma, S.; Fisher, N. Influence of dietary uptake and reactive sulfides on metal availability form aquatic sediments. Science, 287, 2000, p 282-284.

32. Adams, W.; Klimerle, R.; Barnett, J., Jr. Sediment quality: an aquatic life assessment. Environmental Science Technology, 26, 1992, p 1864-1875.

33. Maher, W.; Batley, G.; Lawrence, I. Assessing the health of sediment ecosystems: use of chemical measurements. Freshwater Biology, 41, 1999, p 361-372.

34. Nriagu, J. O. Origin, long range transport, atmospheric deposition and associated effects of heavy metals in the Canadian Environment. In: A report prepared for Atmospheric Environment Service, Environment Canada, 1994.

\section{SAUSUMOS GAISRŲ İTAKA SUNKIŲJŲ METALŲ KONCENTRACIJŲ PADIDĖJIMUI LIETUVOS UPIŲ VANDENYJE}

\section{G. Ignatavičius, G. Sakalauskienė, V. Oškinis}

$\mathrm{S}$ a n $\mathrm{tr}$ a u k a

Aplinkos ministerijos Jungtinio tyrimų centro duomenimis, $2002 \mathrm{~m}$. rugpjūčio ir rugsejjo mėnesių upių vandens kokybès rodiklius palyginus su 1991-2000 m. laikotarpio duomenimis, visų upių, kurių valstybinis monitoringas vykdomas, vandenyje nustatytas sunkiujų metalų (vario, švino ir cinko) koncentracijų padidèjimas 60-81\%. Toks staigus pokytis verčia ieškoti šio reiškinio priežasčių, nes, padidejjus taršai, iš esmès keičiasi vandens telkinių tinkamumas žuvininkystei ir rekreacijai, kyla papildomas pavojus aplinkai ir žmonių sveikatai. $2002 \mathrm{~m}$. liepos ir rugpjūčio mènesiais dèl anomalios sausros Lietuvoje išplito miškų ir durpynų gaisrai. Straipsnyje bandoma pagrissti prielaidą, kad $2002 \mathrm{~m}$. rugpjūtị sunkiujų metalų koncentracijų padidẻjimui Lietuvos upių paviršiniame vandenyje ittakos galèjo turèti gaisrai, pasikeitęs paviršinių grunto sluoksnių pH ir dèl to išnykę gruntiniai geocheminiai barjerai. Dẻl šių priežasčių iš dirvožemio i gruntinius vandenis bei iš upių dugno nuosẻdu i paviršinius vandenis migravo sunkieji metalai, t. y. prasidèjo antrinè tarša.

Prasminiai žodžiai: aplinkos taršos rizika, sunkieji metalai, sausumos gaisrai, upių vandens tarša. 
Gytautas IGNATAVIČIUS. Dr, Assoc Prof, Ecology and Environmental Research Center, Vilnius University (VU).

Doctor of Technological Sciences (environmental engineering), Vilnius Gediminas Technical University (VGTU), 2002. First degree in Biology, Vilnius University (VU), 1992. Former employment: Sc. assistant, VGTU, 1998-2002. Publications: author of over 36 scientific publications. Research interests: environmental risk analysis, environmental pollution assessment.

Gaudenta SAKALAUSKIENĖ. Dr, Environmental Protection Agency.

Doctor of Science (mathematics), Institute of Mathematics and Informatics, 2001. Master of Science (mathematics), Vilnius University (VU), 1993. Former empoyment: Institute of Mathematics and Informatics, 1995-2002. Publications: author of over 17 scientific publications. Research interests: water quality modeling and analysis.

VYTAUTAS OŠKINIS. Dr, Assoc Prof, Dept of Environmental Protection, Vilnius Gediminas Technical University (VGTU). Doctor of Natural Sciences (biology; ecology), Institute of Ecology and Vilnius University (VU), 1993. First degree in Biology, Vilnius University (VU), 1982. Employment: Associate Professor, VGTU, 1993; Institute of Ecology, 1984-1992. Publications: author of over 50 scientific publications. Research interests: applied ecology, environmental pollution. 